\title{
LOCALISED SEVERE INCIDENCE OF BARLEY YELLOW DWARF VIRUS IN WINTER WHEAT
}

\author{
D.A.J. TEULON, J.D. FLETCHER and M.G. CROMEY \\ New Zealand Institute for Crop \& Food Research Limited, Private Bag 4704, \\ Christchurch, New Zealand \\ Corresponding author: teulond@crop.cri.nz
}

\begin{abstract}
Visual symptoms, consistent with severe barley yellow dwarf virus (BYDV) infection, were observed in November 2000 in several mid to late May sown winter wheat crops near Leeston, Canterbury. These crops had not been treated with insecticides for aphid vector control, because of the relatively low numbers of BYDV aphid vectors caught in the nearby $7.5 \mathrm{~m}$ high suction trap at Lincoln during the critical period of virus infection in June and July. Three of the worst crops were of a single cultivar: two crops had yields ca $40 \%$ below expected and another was abandoned for silage. There was little evidence that diseases other than BYDV were responsible for this damage. Serological assays taken in one crop indicated that BYDV incidence was very high. Such high BYDV injury has seldom been observed in Canterbury in recent years and is more consistent with reports from the 1960s. Virus incidence in other regions of Canterbury in 2000 was relatively low. Possible explanations for the higher than expected BYDV incidence in the Leeston crops include a BYDV susceptible cultivar, warmer than normal winter temperatures at lower elevations which may have exacerbated secondary aphid spread within the crops, and unexplained sluggish growth until tillering.
\end{abstract}

\section{GENETIC VARIATION WITHIN NEW ZEALAND POPULATIONS OF PHAEOMONIELLA CHLAMYDOSPORA}

\author{
B. POTTINGER, H.J. RIDGWAY, B.E. SLEIGHT and A. STEWART
Soil, Plant and Ecological Sciences Division, PO Box 84, Lincoln University, Canterbury, New Zealand \\ Corresponding author: pottinb1@lincoln.ac.nz
}

Phaeomoniella chlamydospora has been implicated as the causal agent of Petri Vine Decline (PVD). This disease causes serious economic loss by severely retarding the productivity of young and established vines throughout the world. Phaeomoniella chlamydospora has only recently been recognised in New Zealand and little is known about the genetic composition of New Zealand populations. This study used the molecular technique of universally primed polymerase chain reaction (UP-PCR) to investigate polymorphism within 38 P. chlamydospora isolates. The isolates originated from four distinct geographic locations encompassing five vineyards throughout the North and South Islands and were compared with 6 reference isolates obtained from Italy. Relatively little genetic variation was observed with 5 of the 11 UP-PCR primers identifying 2 genetic groups, and 1 primer (3-2) identifying 3 groups. Genetic variation was present within an individual vine, and within and between New Zealand vineyards. New Zealand isolates were similar to Italian isolates, however, one of the groups distinguished by primer 3-2 did not resemble any of the Italian isolates tested. Assessment of the genetic variation within the pathogen population will provide information about the population composition within New Zealand vineyards and may provide insight into the origin(s) of New Zealand strains. 